Original Article

\title{
In vitro growth of uropathogenic Escherichia coli isolated from a snow leopard treated with homeopathic and isopathic remedies: a pilot study
}

\author{
Ana Paula Kawakami ${ }^{1}$, Lika Osugui ${ }^{1}$, Amarylis Toledo César ${ }^{2}$, Silvia Waisse \\ Priven $^{3}$, Vania Maria de Carvalho ${ }^{1}$, Leoni Villano Bonamin ${ }^{1,4}$ \\ (1) Universidade Paulista, SP, Brazil; (2) HN Cristiano, SP, Brazil; (3)Pontifícia \\ Universidade Católica, SP, Brazil; (4) Universidade de Santo Amaro, SP, Brazil
}

\begin{abstract}
This paper reports the results of incubation of a strain of uropathogenic Escherichia coli (UPEC) isolated from a snow leopard - which had died of septicemia secondary to necro-hemorrhagic cystitis - with homeopathic and isopathic remedies. Methods: UPEC was isolated from heart blood and previously typified for virulence factors; it was incubated with homeopathic remedies Cantharis vesicatoria (urinary tract infection affinity), Mercurius solubilis (from symptoms analysis) and nosode prepared from the actual strain, all in dilution $12 \mathrm{cH}$. Results: 2 patterns of bacterial growth were observed, associated to the quality of nutrients in the culture medium; in rich-nutrient medium, nosode of $E$. coli $12 \mathrm{cH}$ had a significant inhibitory effect; in poor-nutrient medium, Merc 12cH exerted significant inhibitory effect. Conclusion: results suggest that the previous conditions of prokaryote systems may influence the in vitro response to homeopathic and isopathic remedies.
\end{abstract}

Keywords: Urinary tract infection; Felines; Uropathogenic Escherichia coli; Homeopathy; Isopathy

\section{Introduction}

Urinary tract infection (UTI) is one among the most frequent bacterial infections in both animals and human beings [1, 2]. Infection happens when uropathogens colonize the lower or upper urinary tract, giving rise to cystitis and/or pyelonephritis. Escherichia coli is by far the most common agent involved [3].

This study sought to investigate in vitro the action of homeopathic remedies on the growth of uropathogenic E. coli (UPEC) isolated from the blood of a snow leopard (Panthera uncia) which had died from sepsis secondary to necro-hemorrhagic cystitis.

\section{Materials and methods}

Sample: The UPEC strain used in this study was previously isolated from the heart blood of a snow leopard (Panthera uncia) kept in captivity and which had died from sepsis secondary to necrohemorrhagic cystitis. UPEC was previously typified regarding virulence factors: genes codifying adhesins (fim H, sfa), toxins ( $c n f, h l y A)$, siderophore $(f y u A)$ and a pathogenicity island (PAI I -CFT073) marker malX [4].

The primary (matrix) culture of $E$ coli was maintained at $4^{\circ} \mathrm{C}$ during all the study, in the same broth. Samples were obtained at 2 different growing times of matrix culture: 1 and 2 weeks. The samples were inoculated in LB broth and incubated for 2 hours at $37^{\circ} \mathrm{C}$, then, standardized for tube 4 in MacFarland's scale and immediately diluted in scale $1: 10^{6}$ in normal saline.

Homeopathic remedies: Mother tinctures (MT) for the preparation of homeopathic remedies were obtained from Farmácia HN Cristiano, São Paulo. Remedies were prepared in dilution $12 \mathrm{cH}$ according to Brazilian Homeopathic Pharmacopoea $2^{\text {nd }}$ edition [5]; the pharmacy is registered at the Brazilian Agency for Sanitary Vigilance (ANVISA). The last 3 dilutions were prepared in normal saline, to avoid osmotic interference in growth of bacteria. Remedies were prepared the same day they were used.

Remedies selected for this study were:

1- Cantharis vesicatoria: this remedy has particular 
producing intense and fast inflammation tending to necrosis [6]; furthermore, Fontes et al showed the effectiveness of this remedy in dilutions $6 \mathrm{cH}$ and $30 \mathrm{cH}$ in the treatment of rats experimentally infected with $E$. coli [7].

2- Mercurius solubilis: indicated by the analysis of the symptoms presented by the animal donor according to its clinical record (Table 1).

3- Nosode of E. coli: prepared from the isolated strain.

Table 1. Relevant symptoms selected from the clinical records of the donor, a snow leopard.

\section{Elimination symptoms:}

1. Lack of coordination

2. Curved nails; Claudicating

Secondary symptoms: Purulent nasal discharge

3. Hemorrhage

4. Dental calculi

5. Skin ulcer

6. Diarrhea

7. Anemia

Remedies that covered all listed symptoms and respective score according to repertory:
1. Connium (score 10)
2. Cuprum (score 7)
3. Mercurius (score 14)
4. Stramonium (score 8)

In vitro treatment: $100 \mu \mathrm{l}$ of diluted sample were added to $100 \mu$ l of sterile normal saline, incubated in microtitration plate for 30 minutes at environmental temperature and, then, for further 30 minutes after addition of $50 \mu \mathrm{l}$ of Canth $12 \mathrm{cH}$, Merc $12 \mathrm{cH}$, nosode $12 \mathrm{cH}$ and saline (control). After incubation, $50 \mu \mathrm{l}$ of each sample were plated by uniform distribution with Drigalsky loop into BHI agar and incubated for 24 hours at $37^{\circ} \mathrm{C}$.

Another control (baseline) was made incubating bacteria from the same source (saline) directly into BHI agar, without any previous treatment.

At the end of the procedure, the number of colonyforming units (CFU) was assessed blindly. Thirty minutes was the time chosen for the first incubation because it is the normal cycle time of mitosis in $E$. coli.

Statistical analysis: Since Bartlett test indicated that data agreed parametric parameters, the chosen test was ANOVA followed by Tuckey-Krammer. $p=0.05$ was established as criterion of significance.

\section{Results}

Two patterns of response were identified: one (pattern A), exhibited by bacteria originated from 1 week old matrix colony (Figure 1); and the other (pattern B), exhibited by bacteria originated from 2 week old matrix colony (Figure 2).

Since no broth change of matrix colonies was performed during this time, the expected availability of nutrients at 2 weeks was smaller than at 1 week, therefore, the condition of bacteria before 2-hour incubation in LB broth is expected to differ, which indeed was actually verified.

Figure 1. Number of Colony Forming Units of $E$. coli in relation to baseline: pattern A. The table expresses the detailed data. Figure expresses the percentage of growth variation of each group in relation to control (saline). ${ }^{*} \mathrm{p}=0.05$ in relation to baseline; \# $\mathrm{p}=0.05$ in relation to nosode, ANOVA / Tuckey Krammer.

\begin{tabular}{|l|c|c|c|c|c|}
\hline Pattern A & $\begin{array}{l}\text { Sample } \\
\text { (baseline) }\end{array}$ & $\begin{array}{l}\text { Sample 30 min } \\
\text { in normal saline }\end{array}$ & Canth 12cH & Merc 12cH & Nosode 12cH \\
\hline Mean & 8 & 5.44 & 4.58 & 7.08 & 3.08 \\
\hline $\begin{array}{l}\text { Standard } \\
\text { deviation }\end{array}$ & 2.78 & 1.66 & 2.35 & 3.52 & 2.90 \\
\hline Ratio & & 0.68 & 0.57 & 0.88 & 0.38 \\
\hline Variation \% & & -0.31 & -0.42 & -0.11 & -0.61 \\
\hline
\end{tabular}


bacterial growth variation

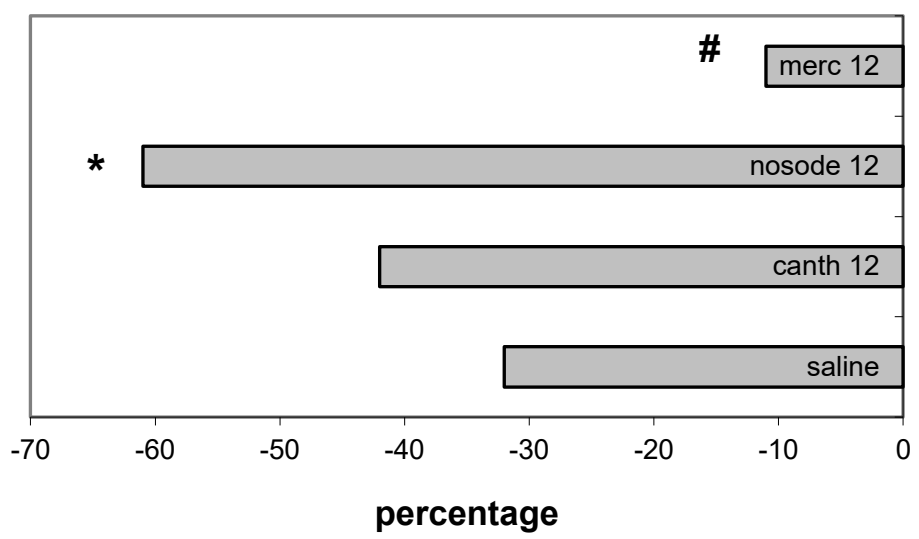

Figure 2. Number of Colony Forming Units of E. coli in relation to baseline: pattern B. The table expresses the detailed data. Figure expresses the percentage of growth variation of each group in relation to control (saline). ANOVA, without significance.

\begin{tabular}{|l|c|c|c|c|c|}
\hline Pattern B & $\begin{array}{c}\text { Sample } \\
\text { (baseline) }\end{array}$ & $\begin{array}{c}\text { Sample 30 min } \\
\text { in normal saline }\end{array}$ & Canth 12cH & Merc 12cH & Nosode 12cH \\
\hline Mean & 23.91 & 30.72 & 22.91 & 18.58 & 24 \\
\hline $\begin{array}{l}\text { Standard } \\
\text { deviation }\end{array}$ & 10.05 & 13.43 & 11.39 & 8.43 & 13.46 \\
\hline Ratio & & 1.28 & 0.95 & 0.77 & 1.00 \\
\hline Variation \% & & 0.28 & -0.04 & -0.22 & 0.003 \\
\hline
\end{tabular}

\section{Bacterial growth variation}

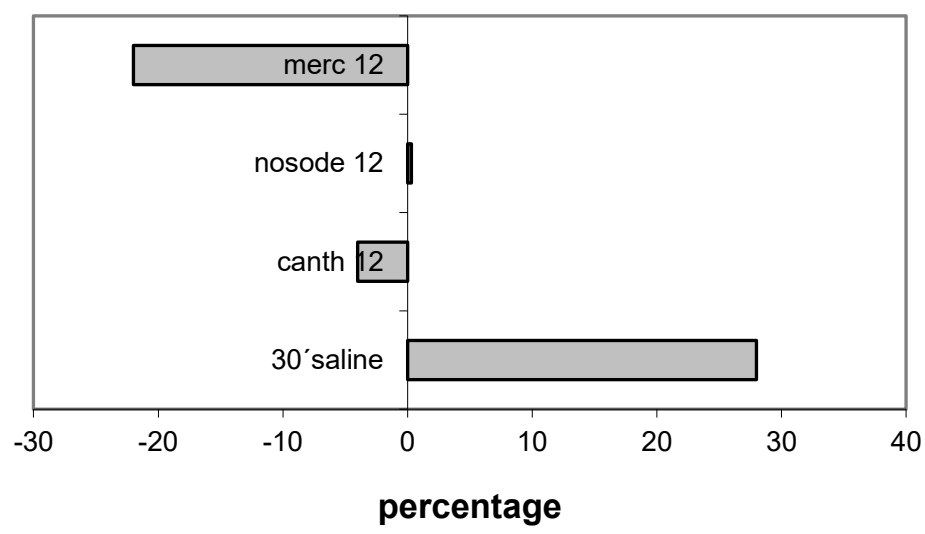

\section{Discussion}

This study involved 4 series of experiments with 3 repetitions in each one; results indicate that $E$. coli obtained from a matrix colony raised in a nutrientrich medium and exposed to nosode $12 \mathrm{cH}$ exhibited significant lower growth in BHI agar by comparison to non treated samples and samples treated with 
Merc $12 \mathrm{cH}$ - to remind, the remedy hypothetically similar to the clinical image of the patient. On the other hand, bacteria obtained from matrix cultured in a poor-nutrient medium exhibited non-significant lower growth ratio under the influence of Merc $12 \mathrm{cH}$, by comparison to non treated samples.

Several studies involving in vitro models in high dilution research has been performed in the last years, some of them showing differences in membrane cell permeability under several homeopathic stimuli, including Mercurius 30c [8]. However, there are few papers in the literature about the in vitro action of high diluted substances in microorganism cultures [9]. Even though, there are some preliminary evidences that biochemical pattern changes can occur in these organisms after exposure to diluted metabolites [10].

The results of this pilot study allow one to suggest that survival of $E$. coli in a nutrient-poor medium might represent a putative selective effect of Mercurius on the best adapted bacteria. New studies are needed to understand this phenomenon better.

These preliminary results suggest that variations in the previous conditions of the studied biological system may elicit variations in the patterns of response to homeopathic and/or isotherapic remedies.

\section{References}

[1] Thoresen SI, Bredal WP, Sande RD. Diagnosis, treatment and long-term follow-up of bilateral upper urinary tract infection (UTI) in a cat. J Feline Med Surg. 2002; 4: 213-220.

[2] Yuri K, Nakata K, Katae H, Yamamoto S, Hasegawa A. Distribution of uropathogenic virulence factors among Escherichia coli strains isolated from dogs and cats. J Vet Med Sci. 1998; 60: 287-290.
[3] Kaper JB, Nataro JP, Mobley HLT. Pathogenic Escherichia coli. Nat Rev. 2004; 2: 123-140.

[4] Carvalho VM. Osugui L, Seltzer AP, Fedulo DL, Lopez RPG, Pestana De Castro AF, Irino Kinue, Catão-Dias JL. Escherichia coli extra-intestinal infection in wild felids: Are these infections underestimated? Proceedings of the 7th congress of the european association of zoo and wildlife veterinarians; 2008; Leipzig: Deutschland. Leipzig: EAZW; 2008. 92-98.

[5] Farmacopéia Homeopática Brasileira. $2^{\text {nd }}$ ed. São Paulo: Atheneu; 1997.

6. Torro AR. Homeopatia veterinária: semiologia, matéria médica e psicossomática. São Paulo: Typus IBEHE; 1999.

[7] Fontes OL, Severino P, Chaud MV, Nascimento GGF, Alves MLF, Gutierrez MA. Ação terapêutica do medicamento homeopático em ratas com infeç̧ão urinária por Escherichia coli. Cultura Homeopática. 2005; 13: 9-13.

[8] Sukul NC, De A, Sinhababu SP, Sukul A. Potentized mercuric chloride and Nux vomica facilitate water permeability in erythrocytes of a fresh-water catfish Clarius batrachus under acute ethanol intoxication. J Alternative Compl Med. 2003; 9: 719-725.

[9] Betti L, Trebbi G, Nani D, Majewsky V, Scherr C, Jäger T, Baumgartner S. Models with plants, microorganisms and viruses for basic research in homeopathy. In: Bonamin LV, editor. Signal and Images: contributions and contradictions about high dilution research. Dordrecht: Springer; 2008. 97111.

[10] Malarczyk E, Jarosz-Wilkolazka A, Kochmanska-Rdest J. Effect of low doses of guaiacol and ethanol on enzymatic activity of fungal cultures. Nonlinearity Biol Toxicol Med. 2003; 1: 167-178.

\section{(c)) BY-NC-ND Licensed to GIRI}

Support: authors declare that this study received no funding Conflict of interest: authors declare there is no conflict of interest

Received: 05 Apr 2009; Revised 01 Jun 2009; Published: 30 Jun 2009

Correspondence author: Leoni Villano Bonamin, leonibonamin@gmail.com

How to cite this article: Kawakami AP; Osugui L; César AT; Priven SW; Carvalho VM; Bonamin LV. In vitro growth of uropathogenic Escherichia coli isolated from a snow leopard treated with homeopathic and isopathic remedies: a pilot study. Int J High Dilution Res [online]. 2009 [cited YYYY Month dd]; 8 (27): 41-44. Available from: http://www.feg.unesp.br/ ojs/index.php/ijhdr/article/view/341/394. 